\title{
FENOMENA PEMBAJAKAN HAK CIPTA KARYA MUSIK DALAM BENTUK VCD DAN DVD: SUATU KAJIAN SOSIOLOGIS DARI TIDAK MAKSIMALNYA SANKSI HUKUM ${ }^{1}$
}

\author{
Oleh: Oksidelfa Yanto \\ Dosen Magister Hukum Universitas Pamulang \\ Email: oksidelfayanto@yahoo.co.id
}

\begin{abstract}
Abstrak
Banyaknya kasus-kasus pembajakan yang bermunculan dilingkungan masyarakat menandakan tidak berfungsinya Undang-undang atau hukum dalam mengujudkan perlindungan hukum bagi hak cipta karya musik. Ini membuat masyarakat semakin tidak percaya pada aparat pemerintah yang ada. Padahal kasus pembajakan hak cipta musik tersebut jelas tidak bisa dianggap enteng. Jika dibiarkan Indonesia akan semakin terancam oleh bahaya pelecahan hukum yang berkepanjangan dan itu akan mengancam kreatifitas anak bangsa negeri ini. Jenis hak cipta yang sering dilanggar adalah pembajakan produksi kaset CD, VCD dan DVD. Maraknya perederan barangbarang bajakan ditempat-tempat terbuka tersebut indikasinya dapat dilihat dari besarnya pasar yang dikuasai oleh pembajak.
\end{abstract}

Kata Kunci: Pembajakan, hak Cipta, Sanksi Hukum

\begin{abstract}
The number of piracy cases are popping up in the environment community indicates malfunctioning of the Act or law in mengujudkan legal protection of copyright musical works. It makes people increasingly do not trust the government officials there. Whereas cases of music copyright piracy is certainly not to be taken lightly. If left Indonesia will be increasingly threatened by the danger of a prolonged legal harassment, and it would threaten the creativity of the people of this country. Type commonly violated copyright piracy cassette production CD, VCD and DVD. Perederan proliferation of pirated goods in places such open indication can be seen from the market dominated by pirates.
\end{abstract}

Keywords: Piracy, copyright, Sanctions Law

\section{A. Pendahuluan}

Dalam pasal 1 ayat (2) TRIPs ${ }^{2}$ (Agreement on Trade-Related Aspects of Intellectual Propety Rights) ada beberapa jenis Hak Kekayaan Intelektual (HKI) yang

\footnotetext{
${ }^{1}$ Naskah diterima tanggal 3 Mei 2016, direvisi 6 Juni 2015, disetujui untuk terbit 24 Juni 2016 dalam Volume 3 No. 1 Juli 2016.

${ }^{2}$ H.S. Kartadjoemena dalam bukunya, GATT WTO dan Hasil Uruguay Round. (Jakarta: Universitas Indonesia, I 997), hal. 252. Menyebutkan bahwa TRIPs merupakan salah satu perjanjian utama yang dihasilkan oleh perundingan Uruguay Round yang teiah berjalan dari tahun I 986 hingga I
} 
mencakup dalam persetujuannya yaitu : hak cipta dan hak-hak terkait lainnya (copy rights and related rights), merek dagang (trademarks), indikasi geografis (geographical indication), desain produk industri (industrial design), paten (patent), desain-layout (topografis), rangkaian elektronik terpadu (layout-design topographies of Integrated Circuit), dan perlindungan terhadap informasi yang dirahasiakan (protecktion oof undisclosed infrmation). Khusus dalam penegakan hukum, TRIPs mewajibkan negara anggota konvensi bern untuk menjamin bahwa prosedur penegakan hukum HKI tersedia di dalam hukum nasional negara anggota masing-masing, sehingga memungkinkan dilakukannya gugatan secara efektif terhadap pelanggaran HKI, termasuk upaya singkat untuk mencegah terjadinya pelanggaran dan upaya yang dapat membuat jera pelanggar HKI yang lain. ${ }^{3}$

Melihat konsideran Perjanjian TRIPs ini, maksud para anggota membuat perjanjian adalah. ${ }^{4}$ (1) untuk mengurangi gangguan dan hambatan dalam perdagangan intemasional. (2) untuk meningkatkan perlindungan yang efektif dan memadai terhadap Hak Kekayaan Intelektual (HKI). (3) untuk menjamin agar tindakan prosedur untuk menegakkan HKI tidak menjadi penghalang bagi perdagangan yang sah.

Bersandar pada ketentuan yang menjadi penyebab adanya usaha dan perhatian untuk hal-hal yang bersifat hak kekayaan intelektual ini, maka ada sebab tertentu yang mendorong kearah bertambahnya perhatian terhadap soal-soal hak kekayaan intelektual intemasional ini dalam tahun-tahun terakhir. Dimana soal HKI telah memperoleh perhatian yang lebih mendalam. Berbagai sebab itu diantaranya disebut bertambahnya masalah-masalah berkenaan dengan pembajakan dan pemalsuan dari produk-produk yang terkenal. ${ }^{5}$

Begitu signiftkannya perlindungan yang diberikan dalam ketentuan diatas, persoalan penegakan hukum dalam upaya melindungi hak cipta industri musik berupa VCD dan DVD di Indonesia mestinya dapat dilaksanakan secara maksimal. Sebab jika kita lihat, persoalan pembajakan hak cipta terutama pembajakan bidang musik terus saja

994. Atas desakan negera maju, masaiah perlindungan hak kekayaan inteiektuai merupakan masaiah yang hams di rundingkan sebagai bagian dari paket peijanjian Uruguay Round.

${ }^{3}$ Nandang Sutrisno, "Implementasi Persetnjuan TRIPs dalam Undang-Undang Hak Cipta Indonesia", Majalah Jurnal Hukum, No 12 Vol.6, 1999, hal. 49-50.

${ }^{4}$ Untuk lebih jelasnya lihat Konsideran Agrement on Trade Related Aspects of Intellectnal Property Rights, ditandatangani di Marrakesh pada tanggal 15 April 1994.

${ }^{5}$ Hak Milik Intelektual Indonesia dan Perjanjian Internasional : TRIPS. GATT. Putaran Uruguay (1994), (Bandung : PT. Citra Aditya Bakti, 1994), hal. ll. 
menjadi cerita lama yang selalu diulang-ulang dari waktu-kewaktu. ${ }^{6}$

\section{B. Rumusan Masalah}

1. Bagaimana inti permasalahan pembajakan VCD dan DVD Karya Musik di masyarakat?

2. Bagaimana putusan pengadilan kasus pembajakan hak cipta?

3. Bagaimana bentuk perlindungan hak cipta karya musik dalam bentuk VCD dan DVD dari tindakan pembajakan menurut Undang-Undang yang ada?

4. Bagaimakah faktor yang mempengaruhi penegakan hukum atas hak cipta serta bagaimana pandangan masyarakatt terhadap peredaran VCD dan DVD bajakan di dalam kehidupannya?

\section{Metode Penelitian}

Adapun metode penelitin yang penulis gunakan dalam penelitian ini adalah dengan menggunakan penelitian yuridis normatif dan penelitian yuridis empiris dengan data sekunder dan primer. Data yang didapat kemudian diolah dan dianalisa untuk menjawab permasalahan yang ada.

\section{Pembahasan}

\section{Inti Permasalahan Pembajakan VCD dan DVD Karya Musik}

Secara yuridis, inti permasalahan pembajakan musik dan lagu dalam bentuk VCD dan DVD ini bertentangan dengan pasal 2 angka $(1)^{7}$ Berne Convention for The Protection of Literary and Artistic Works (Konvensi Bern Untuk Perlindungan Karya Cipta Seni dan Sastra), yang di dalamnya dituliskan bahwa musik adalah suatu ciptaan yang dilindungi. Konvensi Bern ini juga mengatur tentang exclusive rights ${ }^{7}$ (hak-hak

${ }^{6}$ Tidak adanya sanksi yang tegas dan kepastian hukum dari penegak hukum. Ini membuat para pembajak semakin merajalela menjalankan aksinya. Bahkan dalam masyarakat sudah terpatri suatu sikap bahwa para penegak hukum seolah-olah telah memberikan kemudahan bagi pembajak karya orang lain untuk terns mengembangkan sayapnya dalam urusan bajak-membajak.

7 Exclusive rights atau hak-hak eksklusif adalah hak untuk menerjemahkan, hak mempertunjukan dimuka umum ciptaan drama, drama musik, dan ciptaan musik, hak mendeklamasi (to recite) dimuka umum suatu ciptaan sastra, hak penyiaran, hak membuat reproduksi dengan cara dan bentuk apapun perwujudannya, hak menggunakan ciptaannya sebagai bahan untuk ciptaan audiovisual, hak membuat aransemen (arrangements) dan adaptasi (adaptation) dari suatu ciptaan. Otto Hasibuan, Hak Cipta di Indonesia Tinjauan Khusus Hak Cipta Lagu, Neighbouring Rights, dan Collecting Society, PT. Alumni, Bandung, 2008. hal. 40. 
eksklusif) dimana exclusive rights ini dapat dilakukan oleh pihak lain dengan cara memberikan royalti kepada pemilik hak cipta tersebut. ${ }^{8}$

Menurut Armaini Guru SMK di Kota Padang yang penulis hubungi melalui ponselnya, salah satu penyebab masih banyaknya pelanggaran HKI berupa hak cipta di Indonesia adalah karena tidak penegak hukum kurang tegas memberikan sanksi hukum untuk pelaku pembajakan hak cipta dalam bentuk kaset atau lagu. Keinginan masyarakat membeli barang bajakan yang sangat tinggi tidak bisa dilepaskan dari banyaknya barang-barang bajakan yang beredar. Tidak saja VCD dan DVD bajakan namun semua produk bajakan begitu disukai masyarakat. Apalagi harganya sangat murah. Jika masyarakat memilih barang bajakan itu dikarenakan barang bajakan tersebut tersedia di pelosok pasar. Masyarakat tidak lagi menyoalkan mengenai kualitas. Yang penting bisa didengarkan musik dan lagunya. Ketersediaan barang bajakan tersebut pasti diketahui pemerintah dan aparat hukum. Namun persoalan itu dibiarkan tanpa ada yang kemudian mencegahnya. Jadi perlu sanksi hukum kepada semua yang terlibat, yang memproduksi dan yang mengedarkan. ${ }^{9}$

Dikeluarkannya Undang-Undang nomor 12 tahun 1997 mengenai hak cipta tentang perubahan atas Undang-undang Nomor 6 tahun 1982 tentang hak cipta sebagaimana telah diubah dengan Undang-undang Nomor 7 tahun 1987 dan kemudian diubah lagi dengan Undang-undang Nomor 12 tahun 1997 selanjutnya dirubah lagi dengan Undang-undang Nomor 19 tahun 2002 dan terakhir dengan Undang-undang Nomor 28 tahun 2014 merupakan upaya pemerintah Indonesia dalam melakukan harmonisasi hukum HKI Indonesia dibidang hak cipta dengan persetujuan TRIPs. Sasarannya diarahkan kepada terujudnya iklim yang lebih baik bagi tumbuh dan berkembangnya semangat mencipta dibidang ilmu pengetahuan, seni, dan sastra, yang sangat diperlukan dalam pembangunan nasional. ${ }^{10}$

Sementara Susanto seorang advokat di Jakarta menyampaikan pandangannya bahwa barang-barang bajakan sangat mudah kita temui karena harganya sangat murah. Bahkan peminatnya cukup tinggi. Undang-undang sudah memberikan sanksi yang tinggi. Namun orang-orang masih dengan seenaknya menjual dan membeli barang

\footnotetext{
${ }^{8}$ http://id.wikipedia.org/ keyword : "Hak Cipta”diakses pada tanggal 19 maret 2011.

${ }^{9}$ Wawancara penulis dengan narasumber pada tanggal 16 November 2015.

${ }^{10}$ Hak Milik Intelektual Indonesia dan Peijanjian Intemasional, Op.Cit, hal. 50-51.
} 
bajakan. Masih dibiarkannya pelaku pembajakan oleh pihak kepolisian menjamur akan semakin menguatkan bahwa akan sangat jarang keputusan hakim dalam mengadili pelaku pembajakan hak cipta. Padahal putusan hakim bisa menyelesaikan masalah. Efek jera bagi para pelakunya tidak akan pernah ada. Padahal jika kita merujuk kepada ketentuan Undang-Undang Hak Cipta yang pemah ada dan berlaku di Indonesia menerapkan ancaman hukuman dengan sanksi yang terdapat dalam Undang-undang tersebut. Dalam Undang-undang Hak Cipta tersebut ancaman hukumannya bisa mencapai tujuh tahun penjara dan denda maksirnal Rp 500 juta $^{11}$.

\section{Putusan Pengadilan Kasus Pembajakan Hak Cipta}

Dalam banyak kasus kejahatan pembajakan hak cipta bentuk VCD dan DVD, sangat jarang terdapat putusan pengadilan yang menjatuhkan hukuman bagi pelakunya. Kasusnya tidak pernah sampai ke pengadilan. Kalaupun ada hukumannya dijatuhkan kepada penjual VCD dan DVD bajakan sementara para cukongnya jarang tersentuh hukum. Hukumannya hanya beberapa tahun saja. Berarti tidak akan pernah ada rasa keadilan tercapai, karena suatu kasus yang nyata-nyata terjadi dimasyarakat namun tidak diproses secara hukum akan mencederai perasaan keadilan masyarakat.

Menurut Bagir Manan, putusan yang mampu menyelesaikan masalah biasanya dianut oleh hakim-hakim yang social oriented. Penekanan orientasi sosial semacam ini dapat merugikan kepentingan pencari keadilan karena selain menimbulkan ketidakpastian, juga membuat hakim sangat subyektif dan tidak konstisten. Secara tersirat, Bagir Manan mengatakan bahwa putusan yang bertanggungjawab adalah putusan yang baik. Putusan yang bertanggungjawab ialah putusan yang mempunyai tumpuan-tumpuan konsep yang kuat, dasar hukum yang kuat, alasan dan pertimbangan, baik hukum maupun non hukum yang kuat. Orang boleh mengatakan puas dan tidak puas terhadap putusan. Begitu pula, orang boleh menilai putusan mampu menyelesaikan atau tidak menyelesaikan masalah, namun tidak ada yang dapat menyalahkan karena putusan dibuat atas dasar konsep, dasar hukum, dan pertimbangan yang kuat. ${ }^{12}$

Sekarang bagaimana sikap kita melihat pembajakan hak cipta. Mestinya kasus pembajakan itu diproses secara hukum, mulai dari penyidikan, penuntutan dan vonis

\footnotetext{
${ }^{11}$ Wawancara penulis dengan narasumber di Senayan City pada tanggal 12 November 20015.

${ }^{12}$ Bagir Manan, Menegakkan Hukum Suatu Pencarian, (Jakarta: Asosiasi Advokat Indonesia, 2009), hal 189-191.
} 
oleh pengadilan melalui putusannya. Putusan pengadilan senantiasa bersifat individual dan kasuistik. Oleh karena itu, seluruh isi putusan terutama penalaran hukum yang menjadi benang merah lahirnya putusan tersebut, harus dipertanggungjawabkan kepada para pihak. ${ }^{13}$ Dalam hal ini yang disebut para pihak yaitu pencipta dari produk asli yang dibajak.

Banyak hal dikatakan adil dan tidak adil dalam melihat suatu putusan hakim. Dia dikatakan adil apabila kasusnya tersebut diproses dan menghukum pelakunya. Dikatakan tidak adil apabila pembajakan yang terjadi tidak diproses, dan ini menciderai perasaan masyarakat. Keadilan adalah kebajikan utama dalam institusi sosial, sebagaimana kebenaran dalam sistem pemikiran. Suatu teori, betapapun elegan dan ekonomisnya, harus ditolak atau direvisi jika ia tidak benar, demikian juga hukum dan institusi, tidak peduli betapapun efisien dan rapinya, harus direformasi atau dihapuskan jika tidak adil. ${ }^{14}$

Sangat jelas bahwa keadilan menjadi prinsip utama atas suatu tindakan apapun, termasuk putusan pengadilan. Hakim dalam menjatuhkan putusan atas kasus yang ditanganinya hendaknya mengedepan prinsip keadilan, yang pada akhirnya melindungan hak-hak pencari keadilan, dalam kaitan dengan pembajakan hak cipta adalah keadilan dari para pencipta ketika karyanya dibajak dalam bentuk VCD dan DVD.

Dalam berbagai teori dalam ilmu hukum dikatakan, selain memuat kepastian hukum, putusan pengadilan akan dirasakan sebagai putusan yang baik manakala putusan tersebut mampu menyelesaikan masalah. Sebab, pada hakekatnya, putusan pengadilan yang merupakan ujung dari proses peradilan selalu ditujukan untuk mengakhiri atau menyelesaikan suatu perkara atau sengketa antara para pihak. Jika pada akhirnya putusan tidak menyelesaikan persoalan dan justru menimbulkan masalah baru, maka bolehlah kemudian mengatakan putusan itu bukanlah putusan yang baik. Karena tidak mengutamakan kepastian hukum dan keadilan.

Kelemahan-kelemahan tentang argumentasi tentang keadilan itu membuka pintu bagi aliran-aliran hukum untuk melakukan kritik, misalnya Positifisme Hukum yang

${ }^{13}$ Shidarta, Kakateristik Penalaran Hukum dalam Konteks Ke-Indonesiaan, (Bandung: CV.Utomo, 2006), hal. 223.

${ }^{14}$ John Rawls, A Theori Keadilan, dasar-dasar Filsafat Politik untuk Mewujudkan Kesejahteraan Sosial dalam Negara, (Yogyakarta: Pustaka Pelajar, 2006), hal 3-7. 
lebih mengutamakan kepastian hukum dibandingkan keadilan. Cara pandang Positifisme Hukum yang formalistik menghilangkan kemungkinan untuk mempertanyakan apakah norma yang diundangkan itu adil atau tidak. Betapapun buruknya, asal norma itu sudah menjadi hukum positif, hakim dan masyarakat terikat kepadanya. Permasalahan yang muncul kemudian adalah bagaimana jika hukum yang seharusnya melindungi masyarakat dari kejahatan justru dipakai untuk mengabsahkan kejahatan-kejahatan. $^{15}$

Fenomena ini menjadikan aturan hukum terkadang tidak dijadikan dasar untuk menegakkan wibawa hukum oleh aparat terkait yang semestinya menegakkan hukum. Padahal sebuah aturan hukum bertumpu pada kewibawaan dari penegak hukum atau pembentuk Undang-Undang. ${ }^{16}$ Dan ini dapat diujudkan melalui putusan pengadilan.

Jika polisi, jaksa dan hakim serta segenap pelaksana Undang-Undang tidak memiliki nilai dan sikap yang benar dalam menerapkan aturan hukum, sampai kapanpun dan sehebat apapun sanksi dalam suatu aturan tidak akan memiliki nilai efektif dalam menjadikan Indonesia sebagai negara bebas barang-barang bajakan. Atau ketika sikap tidak lagi menghargai aturan hukum, maka disitu terdapat pelanggaran atas Hak Asasi Manusia (HAM). Pelanggaran HAM atas nama rakyat secara keseluruhan. ${ }^{17}$

Jika aparat hukum, mulai dari polisi, jaksa dan hakim sungguh-sungguh ingin menegakkan hukum, tentu saja pembajakan hak cipta dalam bentuk VCD dan DVD bisa dihilangkan atau minimal dikurangi. Suatu tindakan yang serius sangat penting untuk terbentuknya putusan hukum. ${ }^{18}$ Yaitu putusan hukum yang berwibawa dan berkeadilan dalam mewujudkan Indonesia bebas barang bajakan.

Pemerintah harus melaksanakan penegakan hukum atas pelangaran hak cipta. Aparat kepolisian sebagai ujung tombak dalam melakukan penindakan terhadap pelaku mesti bersikap dengan tegas. Penegak hukum harus bergerak tanpa harus menunggu pengaduan dari mereka yang merasa dirugikan. Kalau melihat ada orang yang menjual barang bajakan seharusnya polisi langsung bertindak dan menangkap

${ }^{15}$ Widodo Dwi Putro, Kritik Terhadap Paradigma Positivisme Hukum, (Yogyakarta: Genta Publishing, 1992), hal.24-25.

${ }^{16}$ Mr. J.J.H. Bruggink, Refleksi Tentang Hukum, Pengertian-pengertian Dasar Dalam Teori Hukum, (Jakarta: PT.Citra Aditya Bakti, 1999) hal.125. hal.153.

${ }^{17}$ Cheryl Saunders, Katherine Le Roy, The Rule Of Law, (Australia: The Federation Press,

${ }^{18}$ Jan Gijssels, Mark Van Hoecke, Apakah Teori Hukum Itu, (Bandung:Laboratorium Hukum Fakultas Hukum Universitas Katolik Parahayangan, 2000), hal 5. 
dan tidak menunggu pengaduan dulu. ${ }^{19}$

Dalam Undang-undang Hak Cipta Nomor 7 Tahun 1987 pelanggaran hak cipta telah diklasifikasikan sebagai delik biasa, artinya suatu delik (tindak pidana) akan dilakukan penuntutan oleh jaksa walaupun tanpa pengaduan lebih dahulu dari pihak yang dirugikan. Dalam hal ini, pastisipasi masyarakat tetap mempunyai peran yang tidak kalah pentingnya karena mereka mempunyai hak hukum (legal right) untuk memberikan pengaduan kepada pihak yang berwajib mengenai tindak pidana yang dilihat dan disaksikan.

Delik aduan juga terdapat dalam Pasal 44 Undang-undang No. 6 tahun 1982 yang telah diubah dengan UUHC No 7 tahun 1987 dan diubah lagi dengan UUHC No. 2 tahun 1997. Pengaturan mengenai delik aduan ini kemudian diganti lagi dengan delik biasa dalam UUHC No. 19 tahun 2002 tentang hak cipta. Terakhir UUHC Nomor 28 tahun 2014 delik hak cipta berubah kembali menjadi delik aduan. Jika diperhatikan dari semua UU Hak Cipta diatas dapat diuraikan jenis-jenis tindak pidana hak cipta mencakup;

a) Mengumumkan atau memperbanyak suatu ciptaan atau memberi izin untuk itu. Adapun ketentuan mengenai delik ini terdapat dalam pasal 44 ayat (1) yang berbunyi: "Barang siapa dengan sengaja dan tanpa hak mengumumkan atau memperbanyak suatu ciptaan atau memberi izin untuk itu dipidana dengan pidana penjara paling lama 7 (tujuh) tahun dan atau denda paling banyak Rp. 100.000.000 (seratus juta rupiah)".

Dari semua pengaturan diatas, maka rumusan yang terdapat dalam ketentuan pasal-pasal mengenai hak cipta memiliki beberapa unsur yang dapat dikenakan sebagai delik hak cipta yaitu; 1. Dengan sengaja; 2. Tanpa hak; 3. Mengumumkan atau memperbanyak suatu ciptaan atau memberi izin untuk itu.

${ }^{19}$ Penindakan oleh aparat kepolisian yang masih setengah-setengah dengan menunggu pengaduan dari korban tindak pidana, membuat peran Penyelidik Pegawai Negeri Sipil (PPNS) Depkeh melakukan penelitian terhadap orang atau badan hukum yang diduga melakukan tindak pidana di bidang HKI dan melakukan penelitian atas kebenaran laporan atau keterangan berkenaan dengan tindak pidana tersebutSebab PPNS juga bisa melakukan pemeriksaan di tempat tertentu yang diduga terdapat baban bukti pembukuan, pencatatan dan dokumen lain serta melakukan penyitaan terbadap baban dan barang basil pelanggaran yang dapat di ajukan dalam perkara tindak pidana di bidang HaKI. Setelab itu PPNS dapat menyampaikan basil penyidikannya kepada penuntut umum melalui penyidik Polri, sebagaimana yang telab ditentukan dalam Pasal 107 UU No. 811981 tentang Hukum Acara Pidana (KUHAP). PPNS juga diperkenankan meminta bantuan abli dalam rangka pelaksanaan tugas penyidikan tindak pidana di bidang HaKI. 
Unsur pertama dengan sengaja artinya pelaku berbuat dengan penuh kesadaran dan mengerti bahwa perbuatan itu dilarang oleh undang-undang. Unsur kedua tanpa hak, artinya orang yang memperbanyak atau mengumurnkan ciptaan itu bukan seorang pencipta atau pemegang hak cipta. Sedangkan unsur ketiga mengumumkan atau memperbanyak biasanya terujud dalam bentuk pembajakan baik buku, cassete ataupun program komputer.

b) Menyiarkan, memamerkan, mengedarkan atau menjual kepada umum suatu ciptaan atau barang hasil pelanggaran hak cipta.

Ketentuan mengenai delik ini terdapat dalam Pasal 44 ayat (2) yang berbunyi "Barang siapa dengan sengaja menyiarkan, memamerkan, mengedarkan atau menjual kepada umum suatu ciptaan atau barang hasil pelanggaran hak cipta sebagaimana dimaksud ayat (1), dipidana dengan pidana penajara paling lama 5 (lima) tahun dan atau denda paling banyak Rp. 50.000.000 (lima puluh juta rupiah)".

Dari ketentuan yang terdapat dalam pasal diatas maka dapat kita cermati unsurunsur yang dapat dikenakan sebagai delik hak cipta yaitu : 1) Dengan sengaja; 2) Menyiarkan,memamerkan, mengedarkan atau menjual kepada umum; 3) Barang hasil pelanggaran hak cipta.

Pasal ini memberikan ancaman 5 (lima) tahun dan denda sebanyak lima puluh juta rupiah kepada orang yang menjual barang hasil pelanggaran hak cipta. Bahkan UUHC Nomor 28 tahun 2014 memberikan ancaman pidana nantinya selama 10 (sepuluh) tahun.

Berdasarkan uraian yang dikemukakan dalam pasal-pasal yang mengatur tentang jenis tindak pidana hak cipta diatas, penghukuman atau ancaman pidana yang dijatuhkan kepada pelanggar hak cipta dapat dikenakan hukuman penjara saja atau hukuman denda saja, dan semua itu hanya tergantung kepada hakim yang mengadili perkara tersebut. Melihat penjabaran yang dikemukan dalam delik pelanggaran terhadap hak cipta diatas, maka disatu sisi sebenarnya seluruh Undang- undang yang berkaitan dengan hak cipta sudah sangat efektif sekali untuk menangkal berbagai kasus pelanggaran hak cipta, khususnya pelanggaran hak cipta yang berkaitan dengan pembajakan industri musik.

Akan tetapi, kendala yang kiranya cukup dilematik adalah sanksi hukuman yang dijatuhkan oleh pejabat hukum terkait cukup minim sekali, akibatnya pelanggaran hak 
cipta industri musik terjadi disana-sini tanpa ada yang mampu membendungnya. Pembajakan dan penjual barang bajakan semakin berani dan terang-terangan menjual barang bajakannya, lihat saja di pinggir-pinggir jalan, di emperan took bahkan di Mall sekalipun. $^{20}$

Dari penjabaran ini melihat realitas yang ada dalam kehidupan masyarakat. Dimana masyarakat dikelilingi dengan barang bajakan. Lantas apakah yang salah atau kurang dengan masalah penegakan hukum hak cipta ini. Produk hukumnya sudah ada, aparatnya juga sudah ada, kasusnya juga sudah jelas. Tapi kenapa bisnis pembajakan kaset-kaset illegal makin merajalela dan tumbuh subur diperjual belikan di berbagaibagai pelosok pasar dan toko-toko baik di pusat maupun didaerah.

Mencermati berbagai penelitian yang dilakukan, ada beberapa faktor yang menjadi penyebab seperti. Pertama, faktor peraturan hukumnya atau undang-undang. Kedua, faktor aparat penegak hukum, Ketiga, faktor sarana yang tersedia. Keempat, faktor masyarakat. Kelima, faktor budaya. ${ }^{21}$

\section{Bentuk Perlindungan Hak Cipta Karya Musik dalam Bentuk VCD dan DVD dari Tindakan Pembajakan}

Untuk melindungi karya cipta perlu aparat hukum dengan tegas memberikan sanksi hukum sesuai Undang-undang yang ada. Perlindungan hak cipta sebagaimana diamanatkan Undang-Undang Nomor 19 Tahun 2012 tentang Hak Cipta belum efektif memberikan sanksi hukuman kepada pelaku-pelaku pembajakan hak cipta karya musik VCD dan DVD. Padahal seperti diketahui bahwa berdasarkan Pasal 72 ayat (1) dan ayat (2) Undang-Undang Nomor 19 Tahun 2002 Tentang Hak Cipta, ditetapkan: (1) Barangsiapa dengan sengaja dan tanpa hak melakukan perbuatan sebagaimana dimaksud dalam Pasal 2 ayat (1) atau Pasal 49 ayat (1) dan ayat (2) dipidana dengan pidana penjara masing-masing paling singkat 1 (satu) bulan dan/atau denda paling sedikit Rp. 1.000.000.00 (satu juta rupiah), atau pidana penjara paling lama 7 (tujuh)

${ }^{20}$ Banyaknya pelanggaran hak atas kekayaan intelektual khususnya yang berkaitan dengan pembajakan karya industry musik disebabkan karena tidak adanya sanksi hukum yang sungguh-sungguh dari aparat hukum”. Sehingga membuat para pelaku semakin merajalela menjalankan bisnisnya. Jika penegakan hukum tidak dilaksanakan maka akan mempengaruhi berbagai sektor kehidupan terutama dibidang ekonomi.

${ }^{21}$ Soetjono Soekanto, Faktor-Faktor Yang Mempengaruhi Penegakan Hukum, (Jakarta: Rajawali Pers, 1983), ha1.2. 
tahun dan/atau denda paling banyak Rp 5.000.000.000,00 (lima miliar rupiah). (2) Barangsiapa dengan sengaja menyiarkan, memamerkan, mengedarkan, menjual kepada umum suatu ciptaan atau barang hasil pelanggaran Hak Cipta atau Hak Terkait sebagaimana dimaksud pada ayat (1) dipidana dengan pidana penjara paling lama 5 (lima) tahun dan/atau denda paling banyak Rp 500.000.000,00 (lima ratus juta rupiah).

Kalau peraturan hukum tidak dilaksanakan sebagaimana mestinya, sudah pasti wibawa hukum tidak akan terwujud di negara ini. Agar wibawa hukum dapat terwujud, perlu didukung dengan integritas penegak hukumnya. Namun integritas tersebut akan mudah diabaikan apabila tidak ditunjang dengan Sumber Daya Manusia (SDM). Maka antara integritas, dan sumber daya manusia merupakan jalan keluar agar wibawa hukum bisa tercapai. Pada akhimya mampu mewujudkan kesamaan visi dan misi dalam memberantas segala bentuk kejahatan, termasuk praktik-praktik pembajakan hak cipta.

Negara memiliki kewajiban moral untuk meletakkan fondasi dasar yang tangguh untuk tercapainya demokrasi hukum bagi masyarakat, yaitu berupa perlindungan akan karyanya dari tindakan pembajakan. Gejala pelanggaran hukum akan semakin menjadijadi bila negara tidak mampu mengembalikan kepercayaan rakyat dalam menciptakan dan menumbuhkan wibawa hukum. Menegakkan hukum seadil-adilnya bagi semua masyarakat jalan terbaik menciptakan wibawa hukum. Memberikan sanksi yang tegas sesuai dengan kaedah-kaedah hukum bagi pelaku kejahatan hak cipta bidang musik jelas sesuai dengan tujuan hukum yang didambakan. Tujuan dirumuskannya suatu kaedah hukum adalah memberikan sanksi bagi yang melanggarnya.

Kemudian juga untuk melindungi hak cipta perlu adanya sosialisasi pada masyarakat secara terus menerus mengenai VCD dan DVD karya musik bajakan. Predikat sebagai sarang pembajak karya intelektual memang hal yang patut dibanggakan oleh bangsa Indonesia, karena hal ini bukanlah suatu hal yang baru bagi masyarakatnya. Setiap tahun Indonesia selalu dimasukkan kedalam kategori negaranegara yang tidak mampu mengatasi maraknya aksi-aksi pembajakan. Banyaknya aksi bajak-membajak karya cipta terutama dibidang karya cipta music harus segera dihentikan salah satunya yaitu dengan selalu mensosialisasikan kepada masyarakat secara terus-menerus. Bahkan sekarang merambah di sejumlah mall-mall kita akan dengan mudah membeli compact disc bajakan dengan harga murah. Dalam kehidupan masyarakat kelihatannya berlaku hukum ekonomi yaitu adanya permintaan dan 
penawaran. Selama permintaan (oleh konsumen) dan penawaran (oleh produsen) tetap tinggi, maka pembajakan sukar dihapus. Oleh sebab itulah kedua akar permasalahan tersebut mesti ditangani secara bersamaan. Misalnya dengan cara mensosialisasikan kepada masyarakat.

Faktor lain yang harus dilaksanakan perlu kiranya mengoptimalkan lembagalembaga pengawas untuk memerangi pembajakan VCD dan DVD karya musik. Pembajakan hak cipta bidang industri musik sudah sedemikian parahnya, kondisi ini sangat merugikan para pemegang hak cipta. Jika hal ini dibiarkan berlarut-larut maka jelas akan merugikan dari sisi materinya bagi pencipta. Agar kejahatan ini tidak semakin berlarut perlu adanya satu sistem perlindungan yang terkoordinasi dalam upaya membantu penegakan hukumnya. Misalnya dengan mengaktifkan peran lembagalembaga swadaya masyarakat yang ada. Lembaga-lembaga tersebut tentunya merupakan lembaga yang diduduki oleh mereka yang ahli mengenai hak kekayaan intelektual. Misalnya; Yayasan Klinik Hak Kekayaan Intelektual Indonesia dan Yayasan Karya Cipta Indonesia (YKCI), Asosiasi Industri Rekaman Indonesia (Asiri), Asosiasi Importir Rekaman Video Indonesia dan berbagai LSM. Disamping itu Lembaga Penelitian dari Perguruan Tinggi merupakan mitra strategis dalam melaksanakan sistem hak kekayaan intelektual nasional. Kerjasama pada tingkat nasional dan juga secara tidak langsung merupakan inslitution building dengan lahirnya berbagai sentra, klinik dan pusat hak kekayaan intelektual pada berbagai Departemen, yayasan dan perguruan tinggi, dipusat dan di daerah-daerah.

Kemudian penting juga penanaman nilai-nilai agama ditanamkan kepada mayarakat. Kehadiran agama hampir dipastikan menjadi pandu dalam kehidupan kita. Pandu tersebut berguna untuk mengapai nilai-nilai moral yang lebih baik dalam menghadapi segala persoalan yang ada, termasuk persoalan kesadaran masyarakat untuk menghargai HKI seseorang. Jika nilai-nilai agama dapat diupayakan sedini mungkin, maka nantinya akan dapat dicapai kualitas moral yang baik. Sebab cerminan nilai-nilai agama yang baik dari setiap individu masyarakat akan mencerminkan tingkat moralitas yang baik pula. Sebab tidak mungkin dapat dielakkan penyakit sosial nan akut bangsa ini berpusar pada moral. Kendati luapan reformasi demikian gencar dikumandangkan, 
tetap saja benih moral merajalela kehadiranya. ${ }^{22}$ Dalam konteks negara Indonesia tentu sudah saatnya agama mengambil peran utama di dalamnya. Sejatinya pendekatan nilai-nilai moral dan ajaran agama harus menjadikan manusia untuk berpijak kepada kebenaran dan kebaikan yang digariskan Tuhan Yang Maha Kuasa. Wujud kedekatan kepada Tuhan itulah yang akan termanifestasikan dalam berbagai sikap dan perilaku yang terpuji (akhlaqul karimah) sehingga bisa memberi manfaat dan kebaikan kepada sesama manusia. ${ }^{23}$ Dan dengan memahami agama secara benar akan mendorong terciptanya lingkungan sosial yang lebih baik.

\section{Beberapa Faktor yang Mempengaruhi Penegakan Hukum Hak Cipta}

Apabila kita tinjau faktor yang pertama yaitu faktor peraturan hukumnya, maka ada beberapa persyaratan yang perlu kita perhatikan yaitu mengenai apakah peraturan atau undang-undang itu sudah sistematis, apakah secara kualitatif dan kuantitatif sudah cukup mengatur bidang kehidupan tertentu, apakah peraturan hukum itu telah ditetapkan sesuai dengan persyarakatan yuridis, serta apakah peraturan hukum yang ada itu sudah cukup sinkron. ${ }^{24}$

Bentuk pertanyaan yang terakhir ini kiranya perlu diperhatikan, karena apabila terjadi ketidaksinkronan akan berakibat timbulnya keragu-raguan bagi warga masyarakat untuk taat kepada hukum kerena dianggap tidak adanya kepastian hukum. Padahal kepastian hukum merupakan salah satu tujuan hukum yang berfungsi untuk menciptakan ketertiban. ${ }^{25}$

Jika dilihat pengaturan yang terdapat dalam Undang-undang tentang pelanggaran hak cipta ini, sudah sangat efektif sekali untuk menjerat pelaku pelanggaran hak cipta karena hukuman yang diberikan cukup tinggi sekali. Dikarenakan semua perobahan dan revisi yang telah dilakukan selalu menekankan perobahan terhadap sanksi hukum. Ini bisa kita lihat dengan hukuman denda yang diberikan oleh UUHC yang baru sekarang ini. Dan sangat berbeda sekali bila dibandingkan hal. 8.

${ }^{22}$ MN Harisudin, "Agama Sebagai Medium Prates Sosial", Media Indonesia, 28 Maret 2003,

${ }^{23}$ Muhamad Wahyuni Nafis, "Memikirkan Kembali Pengajaran Agama", Kompas, 25 April 2003 hal. 3.

${ }^{24}$ Ari Pnrwadi, "Pokok-Pokok Strategi Pembangnnan Huknm Di Indonesia", Jnmal Huknm Dan Pembangunan Nomor 3 Tahun XX (Juni 1990), hal. 262 Lebih Jauh Lihat Ismail Saleh, "Budaya Hukum Dan Pembangunan Nasional", Varia Peradilan, No. 36 Tahun III (September 1988), hal. 141.

${ }^{25}$ Ibid. 
dengan UUHC sebelumnya. Contohnya UUHC Nomor 7 tahun 1987 yang hanya memberikan sanksi berupa denda uang setinggi-tingginya Rp 100. 000.000,- (seratus juta rupiah).

Adapun bagi mereka yang dengan sengaja menyiarkan, memamerkan, mengedarkan atau menjual suatu ciptaan yang diperoleh melalui hukum diganjar dengan pidana penjara 5 (lima) tahun dan/atau denda paling banyak Rp 50.000 .000 (lima puluh juta rupiah). Dengan demikian berbagai perubahan dalam penerapan Undang-undang Hak Cipta tersebut setidaknya dari perubahan satu keperubahan yang lainnya selalu menampilkan sanksi hukum yang semakin memberatkan para pelaku pelanggaran hak cipta.

Secara umum ancaman dan ganjaran penjara dan hukum denda bagi pelanggar hak cipta dalam perubahan-perubahan yang terjadi dapat kita lihat dalam UUHC Nomor 12 tahun 2002 khususnya ayat (1) pasal 72 yang menerapkan sanksi denda jauh lebih berat dari pada sanksi denda yang diberikan dalam Undang-undang Hak Cipta yang terdahulu yaitu dengan hukuman penjara 7 (tujuh) tahun dan atau denda Rp. 5. 000.000.000,00 (lima miliar rupiah). Kemudian dalam Pasal 113 ayat 4 UUHC Nomor 28 tahun 2014 memberikan sanksi pidana penjara paling lama 10 (sepuluh) tahun dengan denda Rp. 4.000.000.000 (empat miliar rupiah). Disamping itu ancaman pidana penjara dan hukuman denda dapat dijatuhkan bersama-sama, terbukti dengan adanya kata-kata "dan atau ". Sedangkan ancaman hukuman pada Undang-undang hak cipta terdahulu misalnya UU No. 6/1982 hanyalah salah satu dari ancaman hukuman, yaitu hukuman penjara atau denda, terbukti dengan bunyi ketentuan dengan hukuman "beberapa bulan atau denda beberapa rupiah". ${ }^{26}$

${ }^{26}$ Bentuk pelanggaran hak cipta yang pertama adalah dengan sengaja dan tanpa hak mengumumkan, memperbanyak suatu ciptaan atau memberi izin untuk itu. Termasuk perbuatan pelanggaran ini antara lain melanggar larangan untuk mengumumkan, memperbanyak atau memberi izin untuk itu setiap ciptaan yang bertentangan dengan kebijaksanaan pemerintah di bidang pertahanan dan keamanan negara, kesusilaan, dan ketertiban umum. Pelanggaran hak cipta ini melanggar pasal 72 ayat (1). Pasal 72 ayat (1) menyebutkan, bahwa bagi yang tanpa hak mengumumkan atau memperbanyak suatu ciptaan sebagaimana dimaksud dalam pasal 2 ayat (1) atau pasal 49 ayat (1) dan ayat (2), dipidana dengan pidana penjara paling singkat atau pidana minimum 1 (satu) bulan dan/atau denda paling sedikit Rp 1.000.000,- (satu juta rupiah) atau pidana penjara paling lama 7 (tujuh) tahun atau denda paling banyak Rp 5.000.000.000,- (lima milyar rupiah). Bentuk pelanggaran hak cipta yang kedua adalah dengan sengaja memamerkan, mengedarkan atau menjual kepada umum suatu ciptaan atau barang-barang hasil pelanggaran hak cipta. Termasuk perbuatan pelanggaran ini antara lain penjualan buku dan VCD bajakan. Pelanggaran hak cipta ini melanggar pasal 72 ayat (2). Pasal 72 ayat (2), kemudian menyatakan, bahwa bagi yang sengaja menyiarkan, memamerkan, mengedarkan, atau menjual kepada umum suatu 
Maraknya peredaran VCD/DVD bajakan tidak pernah ditindak tegas oleh aparat Kepolisian. Data yang penulis dapatkan di Polsek Tamansari Jakarta barat menunjukkan bahwa penindakan atas barang bajakan berupa VCD dan DVD tidak ada yang ditangani.

Maraknya peredaran VCD/DVD bajakan juga terjadi di Batam. Pembajakan ini tidak pernah ditindak tegas oleh aparat Kepolisian yang ada di Polda Kepri. Bukan tidak mungkin pembiaran yang dilakukan aparat kepolisian ini karena sudah menerima "upeti" dari distributor VCD/DVD bajakan. ${ }^{27}$

Suatu peraturan yang canggih kalau tidak diikuti dengan pelaksanaan hukum (law enforcement) yang baik tidak akan banyak manfaatnya dalam proses perlindungan hukum pada masyarakat. Kepastian dan perlindungan hukum mempunyai peranan penting dalam suatu masyarakat agar tercipta keteraturan dan ketertiban. Meski sebenarnya peraturan tersebut merupakan deretan huruf-huruf. Peraturan tersebut akan bermakna ketika dia dijalankan oleh orang-orang yang benar mau menegakkannya. Dengan demikian akan muncul kepastian bagi massyarakat. Yaitu kepastian perlindungan hukum. Yang pada akhirnya akan mempunyai peranan penting menciptakan suatu masyarakat yang teratur. ${ }^{28}$ Dengan demikian aturana yang baik dan canggih sekalipun tidak mempunyai makna apa-apa jika tidak "dilaksanakan" dengan sebaik-baiknya oleh pihak-pihak yang berkepentingan. Pasal yang ada dalam setiap UU tersebut harus dilaksanakan, artinya UU jangan hanya tinggai UU, tapi harus diimplementasikan di lapangan.

Banyaknya pelanggaran terhadap hak cipta khususnya yang berkaitan dengan pembajakan industri kaset rekaman telah membuat usaha yang dilakukan pemerintah dalam rangka perlindungan terhadap karya cipta tidak membuahkan hasil yang maksimal. Kemungkinan adanya "oknum" pemerintah atau aparat sendiri, yang mungkin berada di balik aksi pembajakan hak cipta, dan itu sangat sulit sekali untuk diberantas, akibatnya sangat tidak mudah untuk Indonesia dapat memberikan atau menegakkan perlindungan hak cipta musik ini dalam jangka 10 (sepuluh) atau 20 (dua

ciptaan atau barang hasil pelanggaran hak cipta atau hak terkait sebagaimana dimaksud pada ayat (1) dipidana dengan pidana penjara paling lama 5 (lima) tahun dan/atau denda paling banyak Rp 500.000.000,- (lima ratus juta rupiah). Bentuk pelanggaran hak cipta yang ketiga adalah dengan sengaja dan tanpa hak memperbanyak penggunaan untuk kepentingan komersial suatu program komputer. Pelanggaran hak cipta ini melanggar pasal 73 ayat (1).

${ }^{27}$ www.swarakepri.com, Polisi "Legalkan" Peredaran VCD Bajakan di Batam, 20 Desember 2013.

\footnotetext{
${ }^{28}$ Solly Lubis, Serba-Serbi Politik dan Hukum, (Jakarta: PT.Sofmedia, 2011), hal. 55.
} 
puluh) tahun mendatang. ${ }^{29}$

Sulitnya memberikan sanksi hukum kepada para pelaku pembajakan ini juga disebabkan karena mereka mempunyai jaringan yang terorganisir dengan dana yang besar, sehingga bisa saja ada oknum dari aparat yang bermain dalam hal ini. ${ }^{30}$ Padahal segenap masyarakat yang sadar hukum terutama para insan musik sangat mengharapkan sekali hukum ditegakkan yaitu dengan cara menindak mereka yang melakukan praktikpraktik pembajakan.

Secara konseptual terdapat beberapa faktor yang mempengaruhi penegakan hukum hak cipta, yakni faktor undang-undang, faktor aparat penegak hukum, faktor sarana yang tersedia, faktor masyarakat, dan faktor budaya. Faktor-faktor tersebut secara kwantitas belum sepenuhnya mampu mencapai fungsi hukum dan tujuan hukum yang sebenarnya.

Dalam pemikiran hukum modern yang diperkenankan oleh Roscoe pound terdapat dua istilah yang berbeda artinya tetapi diantara kedua istilah itu tidak dapat dipisahkan satu dengan yang lainnya yaitu tujuan hukum dan fungsi hukum. Apabila kita berbicara tentang tujuan hukum maka yang dibicarakan adalah cita-cita hukum yang hendak dicapai (aspek statikanya). Sedangkan untuk fungsi hukum maka yang dibicarakan adalah bagaimanakah bekerjanya hukum (aktifitasnya) dalam masyarakat untuk mencapai tujuan hukum tersebut (aspek dinamikanya). Apabila hendak direduksikan pada suatu hal saja, maka tujuan pokok (primer) hukum adalah ketertiban. Ketertiban adalah tujuan pokok dan utama, merupakan syarat pokok (fundamental) bagi adanya suatu masyarakat manusia yang teratur, merupakan suatu fakta yang objektif yang berlaku bagi segala masyarakat manusia dalam segala bentuknya. $^{31}$

Dengan demikian apabila tujuan hukum adalah ketertiban maka aspek dinamikanya (fungsi hukum) diarahkan pada fungsi hukum sebagai kontrol sosial (social control). ${ }^{32}$ Dilain pihak orang berbicara juga tentang fungsi hukum sebagai

\footnotetext{
${ }^{29}$ Wawancara penulis dengan Bapak Nurdin Aliansyah pengacara di Jakarta pada tanggal 19 Juni 2016.

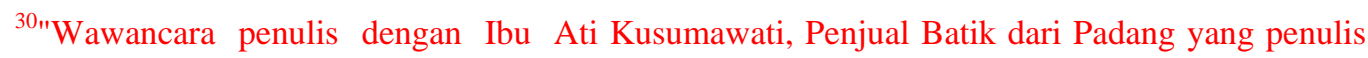
temui di tokonya di jalan M. Yamin, Kota Padang pada tanggal 25 Juni 2016.

${ }^{31}$ Purwadi, Op.Cit, hal. 266.

${ }^{32}$ Mochtar Kusumaatrnadja, Fungsi Dan Perkembangan Hukum Dalam Pembangunan Nasional, (Bandung: Binacipta, tanpa tahun), hal. 2.
} 
sarana perobahan sosial atau sebagai "tool of social engineering" sebagaimana konsep yang dikemukakan oleh Roscoe Pound. Dengan mengetengahkan konsep tersebut Roscoe Pound menempatkan hukum sebagai sarana untuk membangun struktur masyarakat yang tujuannya adalah untuk memberikan kepuasan maksimum kepada masyarakat dengan pengorbanan minimum. Fungsi hukum sebagai sarana perubahan sosial itu akan berpasangan dengan tujuan hukum yang lain. Tujuan hukum yang lain diperkenalkan disini adalah pencapaian peningkatan kualitas hidup manusia, sehingga manusia dalam kehidupanya dapat mengisi pembangunan hukum dengan sebaikbaiknya. Menurut pandangan Satjipto Raharjo pengertian pembangunan hukum itu memiliki aspek ganda yang sebanarnya tidak dapat dipisahkan antara satu dengan yang lainnya. ${ }^{33}$

Kedua aspek pengertian pembangunan hukum itu meliputi modernisasi hukum, yaitu memperbaharui hukum positif sesuai dengan kebutuhan untuk melayani masyarakat seirama dengan perkembangan masyarakatnya dan fungsionalisasi hukum, yaitu memberikan peranan pada hukum untuk ikut dalam mengadakan perubahan pada masa pembangunan. ${ }^{34}$

Dari aspek-aspek ini maka bekerjanya aparat hukum dengan efektif berdasarkan Undang-undang dan peraturan yang ada akan mampu meningkatkan kualitas kehidupan manusia seutuhnya. Dan itu berarti dalam kehidupannya manusia akan merasakan ketentraman dan kedamaian.

Untuk bisa bekerjanya hukum tentu memerlukan dukungan dari aparat hukum itu sendiri. Khusus yang menyangkut pelanggaran hak cipta terhadap pembajakan, maka hukum disini sangat dibutuhkan perananya terutama sekali hukum pidananya. Untuk itulah bekerjanya hukum pidana harus didukung dan dilaksanakan oleh alat perlengakapan negara yang biasanya disebut aparatur penegak hukum yang tata kerjanya pun bisa unik dalam suatu sistem penegakan hukum. ${ }^{35}$

\section{E. Penutup}

Berdasarkan uraian diatas yang tidak kalah pentingnya untuk diperhatikan dimasa-masa mendatang adalah: Pertama, bagaimana agar Undang-undang dan segala

\footnotetext{
${ }^{33}$ Ibid.

${ }^{34}$ Satjipto Rahardjo, Hukum Dan Perubahan Sosial, Cet II, (Alumni Bandung 1983), hal. 231.

${ }^{35}$ Bambang Poemomo, Kapita Selekta Hukum Pidana, (Yogyakarta: Liberty, 1988), hal.90.
} 
peraturan yang ada dan yang telah dibuat itu dapat efektif diberlakukan. Sehingga nantinya Undang-undang tersebut memiliki signiflkansi yang tinggi di tengah kehidupan masyarakat dan akhirnya pelaksanaan perlindungan hak kekayaan intelektual khususnya yang berkaitan dengan pelanggaran hak cipta musik dalam kehidupan masyarakat tidak bermunculan lagi.

Kedua, bagaimana sistem penegakan hukunmya oleh aparat hukum yang ada. Sebab signifikannya penerapan terhadap undang-undang merupakan cerminan dari tingkah laku aparat hukum sendiri. Karena bagaimanapun proses pembuatan maupun bekerjanya Undang-undang hendaknya dapat memberikan sumbangan besar di bidang sistem peradilan pidana khususnya berupa penelitian tentang penegakan hukum, sehingga dapat digunakan untuk memperbaiki bekerjanya aparat penegak hukum ${ }^{36}$

Perlu aparat hukum lebih tegas dalam memberikan sanksi kepada pelaku pembajakan hak cipta. Disamping itu juga perlu aparat hukum untuk lebih mendalami hak kekayaan intelektual khusunya hak cipta. Masih banyak aparat hukum yang belum memahami tentang pelanggaran hak cipta, sehinga keadilan sulit untuk diujudkan. Dan terbatasnya sumber daya manusia (SDM) serta mudahnya aparat hukum yang ada tergoda oleh banyaknya rayuan merupakan kendala utama yang dimasa mendatang harus diperbaiki. Tanpa itu semua bagaimanapun banyaknya Undang-undang tidak akan mempunyai makna dan arti apa-apa. Yang tidak kalah penting, dalam melakukan upaya represif mulai dari proses penyidikan, penuntutan sampai proses peradilan, perlu adanya suatu kerjasama dan koordinasi yang baik dalam rangka penegakan hukum hak atas kekayaan intelektual khususnya yang berkaitan dengan hak cipta industri musik. Kerjasama ini tentunya sesuat dengan bidang masing-masing instansi, misalnya Departemen Perindustrian dan Perdagangan, Ditjen Pajak, Departemen Kehakiman dan HAM khususnya Ditjen Hak Cipta, Paten, Merk, serta praktisi yang bergerak dibindang hak atas kekayaan intelektual.

Hal ini merupakan salah satu upaya mengujudkan harapan masyarakat agar terlaksana proses peradilan yang mumi dan konsekwen, sehingga nantinya akan menimbulkan efek jera bagi pelanggar ketentuan UU di bidang hak atas kekayaan intelektual, khususnya ketentuan perundang-undangan dibidang hak cipta.

\footnotetext{
${ }^{36}$ Rahardjo, Op.Cit., hal 53.
} 
Penegakan hukum hak cipta khususnya dalam menindak pelaku pembajakan CD, DVD dan VCD harus segera dilaksanakan oleh pemerintah yang ada, khususnya aparat hukum terkait. Apalagi kita sudah punya Undang-Undang Hak Cipta yang baru yaitu Undang-Undang Nomor 28 tahun 2014. Dimana sanksi hukuman dalam Undangundang tersebut lebih berat. Menurut Pasal 72 ayat 1 UUHC, dapat diancam pidana penjara maksimum 7 tahun dan/atau denda maksimum Rp 5 milyar. Sementara Pasal 113 ayat 4 UUHC yang baru nomor 28 tahun 2014 dinyatakan bahwa "Setiap Orang yang memenuhi unsur sebagaimana dimaksud pada ayat (3) yang dilakukan dalam bentuk pembajakan, dipidana dengan pidana penjara paling lama 10 (sepuluh) tahun dan/atau pidana denda paling banyak Rp4.000.000.000,00 (empat miliar rupiah). Sekarang tinggal bagaimana Undang-undang yang ada tersebut dimplementasikan oleh pihak terkait yang berwenang. 


\section{Daftar Pustaka}

\section{Buku}

Ari Pnrwadi, "Pokok-Pokok Strategi Pembangnnan Huknm Di Indonesia", Jnmal Huknm Dan Pembangunan Nomor 3 Tahun XX (Juni 1990), hal. 262 Lebih Jauh Lihat Ismail Saleh, "Budaya Hukum Dan Pembangunan Nasional", Varia Peradilan, No. 36 Tahun III (September 1988)

Bagir Manan, Menegakkan Hukum Suatu Pencarian, (Jakarta: Asosiasi Advokat Indonesia, 2009), hal 189-191

Bambang Poemomo, Kapita Selekta Hukum Pidana, (Yogyakarta: Liberty, 1988)

Cheryl Saunders, Katherine Le Roy, The Rule Of Law, (Australia: The Federation Press)

H.S. Kartadjoemena daiam bukunya, GATT WTO dan Hasil Uruguay Round. (Jakarta: Universitas Indonesia, I 997)

Jan Gijssels, Mark Van Hoecke, Apakah Teori Hukum Itu,(Bandung:Laboratorium Hukum Fakultas Hukum Universitas Katolik Parahayangan, 2000)

John Rawls, A Theori Keadilan, dasar-dasar Filsafat Politik untuk MewujudkanKesejahteraan Sosial dalam Negara, (Yogyakarta: Pustaka Pelajar, 2006)

Mochtar Kusumaatrnadja, Fungsi Dan Perkembangan Hukum Dalam Pembangunan Nasional, (Bandung: Binacipta, tanpa tahun)

Muhamad Wahyuni Nafis, "Memikirkan Kembali Pengajaran Agama", Kompas, 25 April 2003.

MN Harisudin, "Agama Sebagai Medium Prates Sosial", Media Indonesia, 28 Maret 2003.

Mr. J.J.H. Bruggink, Refleksi Tentang Hukum, Pengertian-pengertian Dasar Dalam Teori Hukum, (Jakarta: PT.Citra Aditya Bakti, 1999)

Nandang Sutrisno, "Implementasi Persetnjuan TRIPs dalam Undang-Undang Hak Cipta Indonesia", Majalah Jurnal Hukum, No 12 Vol6, 1999

Solly Lubis, Serba-Serbi Politik dan Hukum, (Jakarta: PT.Sofmedia, 2011)

Satjipto Rahardjo, Hukum Dan Perubahan Sosial, Cet II, (Alumni Bandung 1983) 
Shidarta, Kakateristik Penalaran Hukum dalam Konteks Ke-Indonesiaan,(Bandung: CV.Utomo, 2006)

Soetjono Soekanto, Faktor-Faktor Yang Mempengaruhi Penegakan Hukum, (Jakarta: Rajawali Pers, 1983)

Widodo Dwi Putro, Kritik Terhadap Paradigma Positivisme Hukum, (Yogyakarta: Genta Publishing, 1992)

\section{Website}

www.swarakepri.com, Polisi "Legalkan" Peredaran VCD Bajakan di Batam, 20 Desember 2013.

http://id.wikipedia.org/ keyword : “Hak Cipta”diakses pada tanggal 19 maret 2011. 